\title{
Synergic and Antagonistic Action of Active Principles on Chromium-Lead Antagonism - in vivo Experiments
}

\author{
MARIOARA NICULA ${ }^{1}$, NICOLAE PACALA ${ }^{1}$, LAVINIA STEF ${ }^{1}$, IOAN PET $^{1}$, ISIDORA RADULOV ${ }^{2}$, TIBERIU IANCU $^{3}$, MIRELA AHMADI**, $^{4 *}$ \\ DOREL DRONCA*, ADRIANA GHERBON ${ }^{5}$ \\ ${ }^{1}$ Banat's University of Agricultural Sciences and Veterinary Medicine King Michael I of Romania from Timisoara, Faculty of \\ Bioengineering of Animal Production, 119 Calea Aradului, 300645, Timisoara, Romania \\ 2Banat's University of Agricultural Sciences and Veterinary Medicine King Michael I of Romania from Timisoara, Faculty of \\ Agriculture,119 Calea Aradului, 300645, Timisoara, Romania \\ ${ }^{3}$ Banat's University of Agricultural Sciences and Veterinary Medicine King Michael I of Romania from Timisoara, Faculty of \\ Agricultural Management, 119 Calea Aradului, 300645, Timisoara, Romania \\ ${ }^{4}$ Banat's University of Agricultural Sciences and Veterinary Medicine King Michael I of Romania from Timisoara, Faculty of \\ Veterinary Medicine, 119 Calea Aradului, 300645, Timisoara, Romania \\ ${ }^{5}$ University of Medicine and Pharmacy Victor Babes Timisoara, Faculty of Medicine, 2 Eftimie Murgu Sq., 300041, Timisoara, \\ Romania
}

\begin{abstract}
Heavy metal pollution of the aquatic environment has become a major concern for the world. As natural water pollutants, heavy metals are among the most toxic due to their cumulative effect and the difficulty of being converted into insoluble compounds in the surface waters. Lead and its compounds are toxic to aquatic organisms, especially fish, even at low concentrations, being able to replace essential elements from the organism. Thus, we tested the concentration of chromium in tissues of Prussian carp's fingerlings, exposed to chronic lead intoxication, following the synergic and antagonistic effects of some active principles from garlic and chlorella in various tissues. Our experiment was performed on 120 Prussian carps for 21days as following: $\mathrm{C}$ group (without treatment), E1 group ( $75 \mathrm{ppm} \mathrm{Pb}$ into water as $\mathrm{Pb}\left(\mathrm{NO}_{3}\right)_{2} \times 1 / 2 \mathrm{H}_{2} \mathrm{O}$ ), E2 group ( $75 \mathrm{ppm} P \mathrm{~Pb}$ into water+2\% freeze dried garlic in feed), E3 group ( $75 \mathrm{ppm}$ Pb into water $+2 \%$ freezedried chlorella in feed). At the end of the experimental period, tissue samples (gills, muscle, heart, skin and scales, intestine, liver, brain, gonads, and kidney) were sampled after anaesthesia. Atomic Absorption Spectrometry was used to determination of chromium concentrations in tissues. Our results revealed that freeze-dried garlic presented antagonistic effect between administrated lead and tested chromium concentration, while the chlorella showed antagonistic and synergic action, depending on the organ tissue that we had analysed.
\end{abstract}

Keywords: lead, chromium, garlic, chlorella, fish

Environmental protection is one of the most acute and complex problem of the present all over the world. Interrelations of the environment with the fields of the economy and with all aspects of social life determine mutual conditioning. The impetuous economic and social development of human communities has induced accelerated environmental change, deeply disrupting the natural balance of processes in the biosphere. Among different types of pollution, chemical pollution change is more dangerous affects all the biosphere components. Intense environmental pollution also affects the activity of aquatic ecosystems. Radioactive, chemical or biological impurities endanger their balance. The presence of chemical pollutants in water can have particularly serious ecological consequences by restructuring biocoenosis, altering their integrity and, implicitly, aquatic ecosystems.

Surface water contamination is caused by effluent from factories using such substances in production processes. The biological treatment of surface waters can be seriously compromised due to the destruction by this group of pollutants of a large number of microorganisms and inhibition of the methane fermentation process in the sludge.

Harmful action of pollutants can be indirectly manifested by diminishing oxygenation, changing the $\mathrm{pH}$ and other physical and chemical properties of water, but also directly on the organisms that populate the aquatic basin. Some substances in the aquatic environment can induce mutations with serious consequences for future generations, with deep implications for the stability of the ecosystem.

Heavy metals and their toxic salts - which exhibit great stability, are considered dangerous agents for aquatic animals. U. S. Environment Protection Agency (EPA) has listed the eight most common heavy metal pollutants: As, $\mathrm{Cd}, \mathrm{Cr}, \mathrm{Cu}, \mathrm{Hg}, \mathrm{Ni}, \mathrm{Pb}$, and $\mathrm{Zn}$ [1].

Some heavy metals are essential components of many respiratory enzymes and pigments, while $\mathrm{Pb}, \mathrm{Cd}$ and $\mathrm{Hg}$ are non-essential and highly toxic, even at very low levels, especially if they accumulate in the metabolic active sites. Toxic metals interfere with the normal metabolic functions of the essential elements. Synergistic and antagonistic (fig. 1) relationships can be established between minerals elements [2].

Others inorganic elements can compete with a specific element for favourable binding sites [3-5]. Lead is number 2 on the Agency for Toxic Substances and Disease Registry

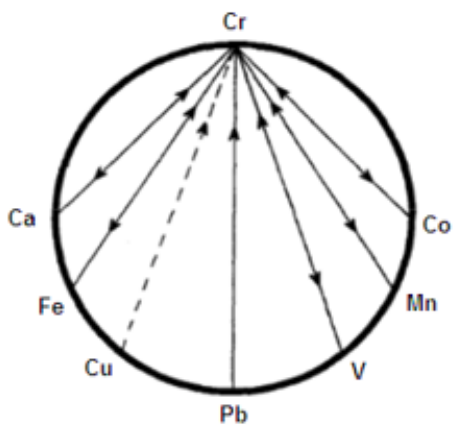

Fig. 1. Direct and indirect antagonistic relationship between chromium and other minerals (solid lines indicate direct antagonism; dotted lines indicate indirect antagonism)

* email: mirelaahmadi@gmail.com; ddronca@animalsci-tm.ro 


\begin{tabular}{|l|c|c|c|c|}
\hline \multicolumn{1}{|c|}{ Ecosystem } & PNEC & PEC & RCR & Risk? \\
\hline Freshwater ( $\mu \mathrm{g}$ Pb/L water) & 3.1 & 0.61 & $<1$ & No \\
\hline Marine water ( $\mu \mathrm{g} \mathrm{Pb/L}$ water) & 3.5 & 0.05 & $<1$ & No \\
\hline $\begin{array}{l}\text { Freshwater sediment } \\
\text { (mg Pb/Kg dry sediment) }\end{array}$ & 174 & 100 & $<1$ & No \\
\hline Marine sediment (mg Pb/Kg dry sediment) & 164 & 53 & $<1$ & No \\
\hline
\end{tabular}

Table 1

CRITICAL VALUES USED FOR RISK ASSESSMENT OF LEAD IN AQUATIC ENVIRONMENTS IN EUROPE

PNEC=Predicted No Effect Concentration; $\mathrm{PEC}=$ Predicted Environmental Concentration; $\mathrm{RCR}=$ Risk Characterisation Ratio

(ATSDR) Top 20 Hazardous Substances List [6]. Pb can enter in aquatic environments from natural sources as weathering of soil, forest fires and volcanoes, or anthropogenic source household uses, waste management, savage treatment plants, industry, or traffic [7].

Van Sprang et al. (2016) [8] assessing the environmental risk of lead in European surface water and they have concluded that lead is not generally harmful to aquatic organisms at ambient levels (table 1), but accidental leakage of waste from various factories or also deliberate spills of pollutants containing lead - in conditions and concentrations that can change the water characteristics - affecting the health of the ecosystem.

Aquatic organisms, such as fish, accumulate pollutants directly from contaminated water and indirectly via the food chain. Toxic substances can enter the body through different pathways, and then they are transported by the internal environment to different tissues, the site of biotransformation into metabolites that can accumulate or can be removed. At the cellular level, chemicals can act directly or via resulting metabolites with cellular macromolecules, the most likely being nucleic acids. The inefficient operation of the repair mechanisms results in the production of cellular injuries, which can be unrepaired.

The intensity of the toxic action is manifested by a number of factors that take into account the nature of the toxic substance, the response of the organism to which the toxic action or environmental factors have been exerted, and this can potentiate or diminish the effect of the toxic chemical. Harmful chemicals, medications or drugs, agricultural (insecticides or pesticides) or industrial pollutants can alone each other or in association to predisposing or aggravating various medical conditions $[6,9,10]$.

An advantage in the fighting for survival is the ability of fish to recognize and avoid heavy metals compounds, as well as the ability to accommodate to high concentrations of heavy metals. For example, negative reaction to lead occurs at 0.4-1 mg/L [5]. But large amounts of lead may cause acute or chronic toxicity (poisoning) as a result of exceeding the body detoxification capacity and accumulation in soft tissue. Allopathic (conventional), alternative and naturopathic treatments are used today to remove heavy metals from human organism. Chelation therapy is the most commonly used therapeutic strategy in heavy metal intoxication [11].

Despite their high removal capacity for heavy metals, synthetic chelators as DMSA (2,3-Dimercapto-1propanesulfonic acid), EDTA (Ethylene diamine tetraacetic acid), BAL (dimercaprol known also as British antiLewisite), D-penicillamine can intensify the excretion of essential elements [12,13].

But many herbs and natural detoxifying agents contain antioxidant and chelating compounds that work synergistically or associated resulting heavy metal detoxification in human and animals [14-17]. A large number ot research teams have tested the heavy metals detoxifying ability of garlic and chlorella [18-21].

Garlic (Allium sativum) contains two main components of therapeutic importance: the allyne which is enzymatically converted to allicin and the bioactive compounds with sulfur. Its sulfide groups oxidize mercury, copper, cadmium and lead, making them soluble in water and facilitating their excretion [22]. It has been proven that garlic have chelating effect in some animal studies [23].

Chlorella is a very effective chelator of chemicals and heavy metals in the body, due to its high chlorophyll content - almost 10 times higher than in alfalfa [24]. Phenolic compounds, salicylic, cinnamic, synaptic, chlorogenic, and caffeic acids found in the chlorella methanolic extract are associated with its strong antioxidant capacity [25]. A study on laboratory mice, published in Food Chemistry Toxicology in July 2008, demonstrated that chlorella treatment significantly reduces levels of lead in blood and tissues [26].

Preventing or limiting the action of pollutants on vegetal or animal organisms requires knowledge of the effects and mechanisms of their action. Zinc, copper, manganese, iron, chromium, and lead can interfere with the normal function of hundreds of vital metallo-enzymes [27]. Other experimental studies presented synergic and antagonistic effects between minerals after intoxication of rabbits of rats with zinc, manganese, or lead with, or without natural products as toxicological protectors [28-33].

Edible fish are considered as excellent bioindicators for assess the toxic effect of heavy metals on biota health and aquatic pollution [34]. Considering these aspects, the present study was carried outto: 1) monitor and determine the impact of experimental lead intoxication on $\mathrm{Cr}$ tissue level in Prussian carp; 2) to investigate the effect of experimentally added garlic (Allium sativum) and chlorella (Chlorella pyrenoidosa) powder on lead relation with chromium.

\section{Experimental part}

120 Prussian carps (Carassius gibelio Bloch), weighing $22-25 \pm 10 \mathrm{~g}$ from a local fish farm were held in four glass aquariums ( 30 fish/aquarium), each containing $60 \mathrm{~L}$ fresh water as follow: the control (C) group was reared in freshwater, $\mathrm{Pb}$ free; group 2 was exposed to $75 \mathrm{ppm} \mathrm{Pb}$ into water as $\mathrm{Pb}\left(\mathrm{NO}_{3}\right) \times 1 / 2 \mathrm{H}_{3}$; group 3 was received 75 ppm $\mathrm{Pb}$ into water as $\mathrm{Pb}\left(\mathrm{NO}_{3}\right) \times 1 / 2 \mathrm{H}_{2} \mathrm{O}$ and $2 \%$ freezedried garlic in feed; group 4 was given 75 ppm Pb into water and $2 \%$ freeze dried-chlorella in feed.

Fish were acclimatized for 2 weeks under laboratory conditions before being used in the experiment and were fed two times/day with pelleted commercial fish food. They have benefited from an alternating $12 \mathrm{~h}$ light and $12 \mathrm{~h}$ darkness regime and a weekly water and pollutant metal renewal in aquariums. The physical-chemical parameters of aquarium water (temperature, $\mathrm{pH}$, dissolved oxygen, hardness, nitrites, nitrates) were checked constantly. A 
Hanna Hi 9145 Water Resistant Oxygen meter has been used to measure water temperature and dissolved oxygen and a Termates kit for $\mathrm{pH}$, hardness, nitrites and nitrates.

Fish from all groups including the control, after 21 days of experiment, were euthanized with clove oil after a $12 \mathrm{~h}$ starving period. The major organs under study (gills, muscle, heart, skin and scales, intestine, liver, brain, gonads, kidney) were isolated and digested, and then metal concentration was determined using atomic absorption spectrometry (AAS).

Data were reported as a significant level at $p<0.05$. Testing differences between means was realized by ANOVA completed with post-hoc Tukey test.

\section{Results and discussions}

Our experimental results are presented in figure 2 and statistical correlations are exposed in table 2.

In our study, chromium tissue concentrations were above the maximum tolerable values provided by international institutions (fig. 2), except the muscle, where the measured value was under the safety limit $(0.47 \mathrm{mg} /$ $\mathrm{kg}$ ). The values we recorded in the control group are lower than those showed by Azmat et al. [35] -by comparison, suggesting that extrinsic - metal concentration, time of exposure, way of metal uptake, environmental conditions [36] and intrinsic factors - fish age, feeding habits, genetic tendency, health status or tissue-specific capacity for uptake, retention and excretion [37-39], can cause variations in the tissue distribution of the metal.
The presence of lead in water led to a severe decrease $(p<0.001)$ (table 2$)$ in tissue chromium concentration to less than $1 \mathrm{mg} \mathrm{kg}^{-1}$, which can be explained by the fact that $\mathrm{Pb}$ tends to substitute the essential metals and compete for biological ligands [40]. The direct antagonism exerted by $\mathrm{Pb}$ to $\mathrm{Cr}$ takes place on metabolic or absorptive level, as D. L. Watts has shown [2]. The antagonistic effect of $\mathrm{Pb}$ is evident even when the addition of freeze driedgarlic determines some extent of its complexion, $\mathrm{Cr}$ being maintained at relatively low values. The exception is the skin and the intestine, where the active principles of the garlic powder manage to completely counteract the antagonistic effect of chromium on lead. Only chlorella powder has the ability to bring the chromium tissue level very close to that of the control or even if leaded to a more efficient chromium uptake for most analysed tissues.

As an essential micronutrient, $\mathrm{Cr}^{3+}$ is involved in carbohydrates metabolism and insulin action in order to manage the nutrients with energetic role from organism [40]. Traces $\mathrm{Cr}^{3+}$ has a role in peripheral insulin activities by forming a ternary complex with insulin receptors, facilitating the attachment of insulin to these sites in mammals. Chromium deficiency in humans can occur in children suffering from protein-calorie malnutrition and in elderly patients with impaired glucose tolerance, but this is not well demonstrated. Prolonged consumption of a synthetic diet withoutchromium supplementation can lead to impaired glucose metabolism and possible effects on growth, on lipids and proteins metabolism.

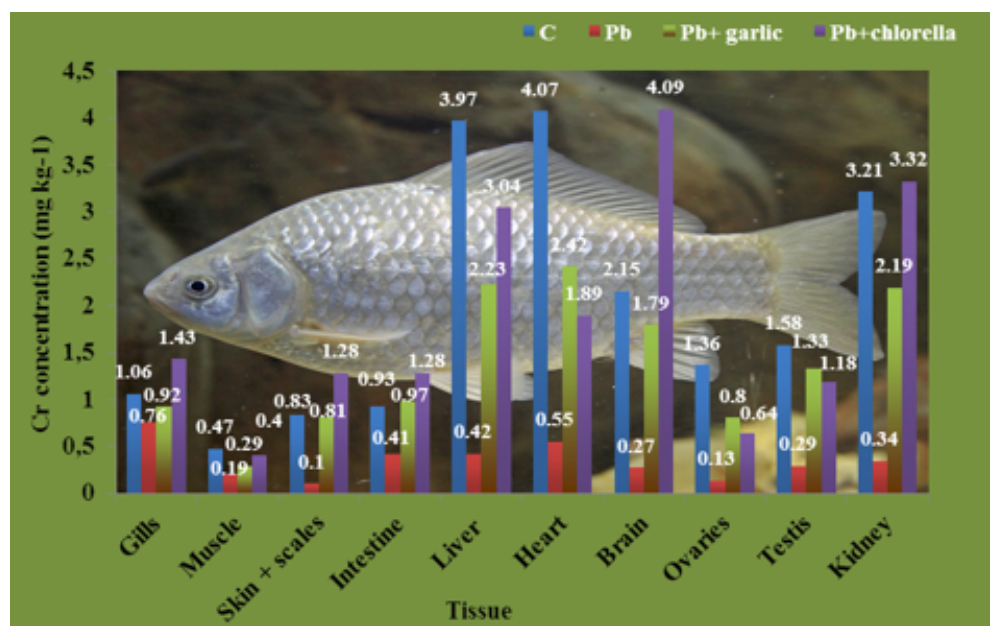

Fig. 2. Influence of water-borne lead exposure on chromium in Prussian carp tissue (average values)

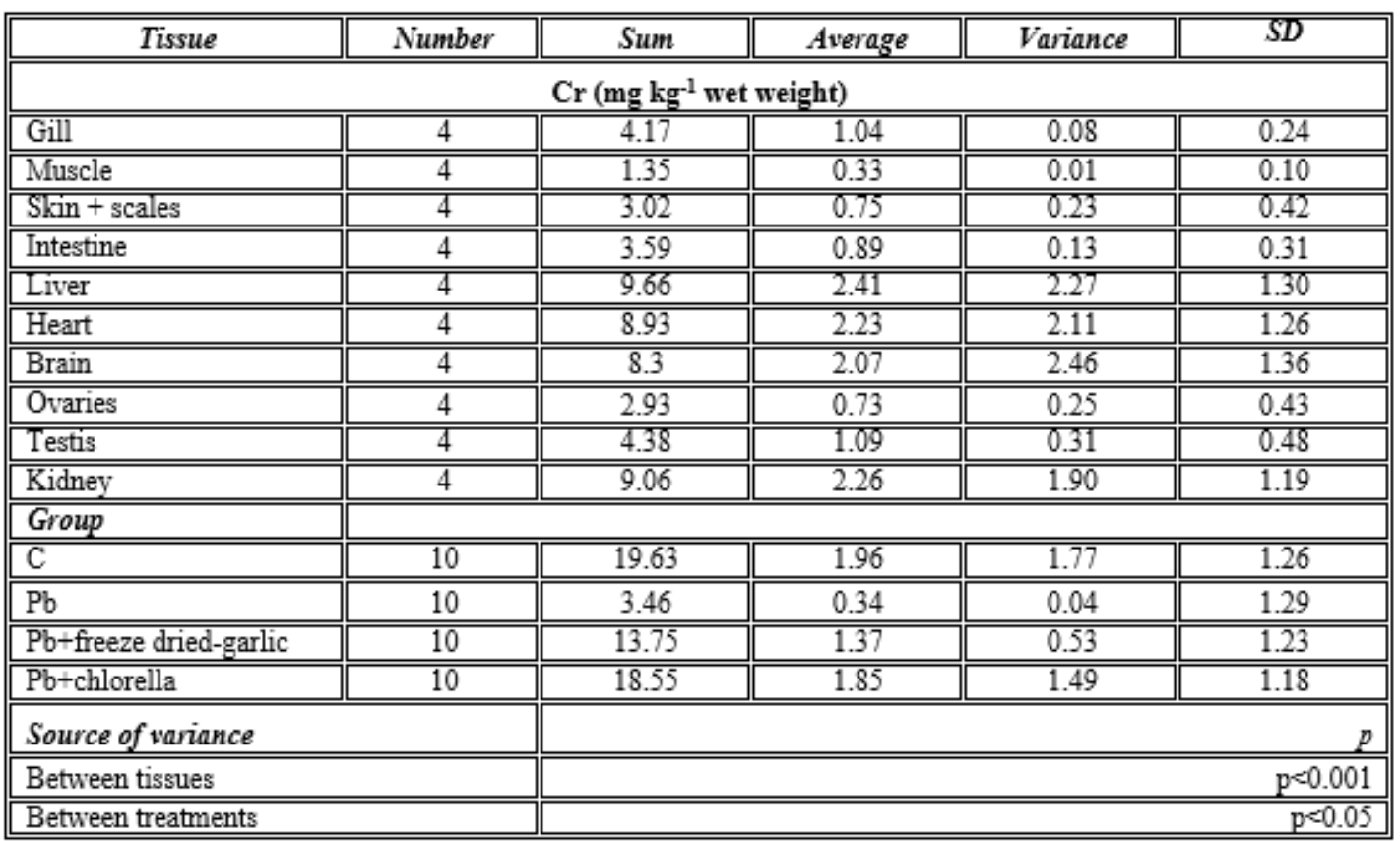

Table 2

FISH TISSUE CHROMIUM CONCENTRATION STATISTICAL SIGNIFICANCE OF LEAD TOXICITY 
Liu etal. (2010) testing chromium picolinate supplement on growth and haematology parameters of grass carp (Ctenopharyngodon idellus), have found that chromium could modify serum carbohydrate and lipid metabolism profile, observed that the optimal dietary chromium level according to growth was $0.8 \mathrm{mg} \mathrm{kg}^{-1}$ [41].

The influence of dietary chromium on glucose metabolism in fish was investigated by Hertz and collaborators in 1989 and Shiau and Lin in $1993[42,43]$. Thereby, Hertz found that chromium salts improved glucose utilization and inhibited gluconeogenesis, probably by modulating the endogenous insulin activity in carp, while Shiau supplemental dietary chromium increased the weight gain, energy deposition and liver glycogen content in tilapia fed glucose diets.

According to International Atomic Energy Agency (IAEA), tolerable value for chromium in fish must not exceed $0.73 \mathrm{mg} / \mathrm{kg}$ weight [44], while Food and Environment Protection Act (FEPA) has established less than $0.1 \mathrm{mg} / \mathrm{kg}$ dry weight [45].

On the other hand, Gwyneth [46] has considered that chromium asymptotic levels for fish kidney were found from $3.5 \mathrm{mg} / \mathrm{kg}$ to $9.4 \mathrm{mg} / \mathrm{kg}$ in kidney; $0.1-1.7 \mathrm{mg} / \mathrm{kg}$ in liver; 0.01-0.3 mg/kg in muscle. Azmat et al., (2018) [35], reported tissue Cr levels associated to normal background concentrations in control groups of three carp species reared under chronic stress of chromium.

\section{Conclusions}

Our results indicate that lead intoxication can contribute to chromium tissue losses or can decrease the chromium absorption in most of the fish organs. Active principles from edible garlic or chlorella could potentially fight againsthigh toxic effect of lead by the containing chelatante and by its antioxidative properties. Thereby, our study demonstrates that natural plant or algae could be used as natural prevention or detoxification agents.

\section{References}

1.ZHONGMIN, J., SIYUE, L., WANG, L., Scientific Reports, 2018, 8, no. 3256.

2.WATTS, D.L., Orthomolecular Medicine, 1990, 5, no. 1.

3.TAKESHI, W., VISWANATH, K., SHUICHI, S., Aquaculture, 1997, 151, p. 185.

4.NICULA, M., PACALA, N., RADULOV, I., AHMADI, M., DRONCA, D., GHERBON, A., Rev. Chim. (Bucharest), 68, no 9, 2017, p. 2006.

5.ATSDR, Top 20 Hazardous Substances from the CERCLA Priority List of Hazardous Substances for 2001.

6.NICULA, M., PACALA, N., STEF, L., PET, I., DRONCA, D., GHERBON, A., AHMADI, M., Rev. Chim. (Bucharest), 68, no 12, 2017, p.2747.

7.KAMARUZZAMAN, B.Y., ONG, M.C., RINA, S.Z., The American J ournal of Applied Sciences, 2010, 7, no. 3, p. 309.

8.VAN SPRANG, P., NYS, C., BLUST, R.J., CHOWDHURY, J., GUSTAFSSON, J.P., JANSEN, C.L., DE SCHAMPHELAERE, K.A., Environ.Toxicol.Chem., 2016, 35, no. 5, p.1310.

9.STANCU, A., GHISE, A., PENTEA, M., VELIMIROVICI, D.E., PASCA, S., CARPINISAN, L., CRISTINA, R.T., Mat. Plast., 54, no 2, 2017, p.302. 10.BERCEANU VADUVA, D.M., VELIMIROVICI, D.E., BERCEANU VADUVA, M.M., STANGA, L., PETRESCU, H., RADA, M., CIPU, D., BERCEANU VADUVA, B.M., RADULESCU, M., Mat. Plast., 55, no 3, 2018, p. 372. 11.KUSAL, K.D., Al Ameen J. Med. Sci., 2009, 2, no. 2, Special, p.43. 12. EHRLICH, J., New York City Department of Health and Mental Hygiene.

13.TORRES-ALANIS, O., GARZA-OCANAS, L., BERNAL, M.A., PINEYROLOPEZ, A., J. Toxicol.-Clin. Toxicol., 2000, 38, no. 7, p.697.

14.UCHIKAWA, T., KUMAMOTO, Y., MARUYAMA, I., KUMAMOTO, S., ANDO, Y., YASUTAKE, A., J. Toxicol. Sci., 2011, 36, no 1, p.121.

15.ABDALLA, F.H., BELLÉ, L.P., DE BONA, K.S., BITENCOURT, E.R., PIGATTO, A.S.M., MORETTO, B., Food and Chemical Toxicology,2010, 48, no. 1, p.417.
16.DELDAR, K., NAZEMI, E., BALALI-MOOD, M., Journal of Birjand University of Medical Sciences, 2008, 15, p.11.

17.NICULA, M., PACALA, N., STEF, L., PET, I., BENCSIK, I., RADULOV, I., IANCU, T., TULCAN, C., DRAGOMIRESCU, M., DRONCA, D., BERBECEA, A., DUMITRESCU, G., SIMIZ, E., AHMADI, M. MARCU, A., Animal Science and Biotechnologies, 2017, 50, no. 1, p.265.

18.KUMAR, P., PRASAD, Y., PATRA, A.K., RANJAN, R., SWARUP, D., PATRA, R.C., ANDPAL, S., Sci. Total Environ., 2009, 407, p.5024.

19.SURU, S.M., BioMetals, 2008, 21, no. 6, p.623.

20.UCHIKAWA, T., KUMAMOTO, Y., MARUYAMA, I., KUMAMOTO, S., ANDO, Y., YASUTAKE, A., J ournal of Toxicological Sciences, 2011, 36, no. 1, p.121.

21.NICULA, M., PACALA, N., STEF, L., PET, I., DRONCA, D., AHMADI, M., GHERBON, A., Rev. Chim. (Bucharest), 69, no. 4, 2018, p.986. 22.ABD EL AZEEM MAY, H., HASSAN, A.M., HUSSEIN, M.M., ABD EL WAHED ZAMZAM, H., SALEH, R.E., SCVMJ , 2012, XVII, no. 1, p.57. 23.KIANOUSH, S., BALALI-MOOD, M., MOUSAVI, S.R., MORADI, V., SADEGHI, M., DADPOUR, B., RAJABI, O., SHAKERI, M.T., Basic Clin. Pharmacol. Toxicol., 2012, 110, no. 5, p.476.

24.TRAVESIO, L., CANIZARES, R.O., Bull. Environ. Contam. Toxicol., 1999, 62, p.144.

25.MIRANDA, M.S., SATO, S., MANCINI-FILHO, J., Boll Chim Farm., 2001, 140, no. 3, p.165.

26.MARY, L.S. QUEIROZ, TORELLO, C.O., PERHS, S.M.C., ROCHA, M.C., BECHARA, E.J.H., MORGANO, M.A., VALADARES, M.C., RODRIGUE, A.P.O., RAMOS, A.L., SOARE, C.O., Blood and Chemical Toxicology, 2008, 46, p.3147.

27.DRONCA, D., PACALA, N., OROIAN, T., TELEA, A., VINTILA, T., PET, I., Bulletin of the USAMV Cluj-Napoca, Animal Husbandry and Biotechnologies, 2006, 62, p.209.

28.AHMADI, M., PUP, M., OLARIU, L., VERMESAN, H., PREJ BEANU, R., Rev. Chim. (Bucharest), 59, no. 9, 2008, p. 982.

29.PREJ BEANU, R., AHMADI, M., SCURTU, M., VERMESAN, D., OLARIU, L., Rev. Chim. (Bucharest), 62, no. 7, 2011, p.750.

30.DELEANU, B., SCURTU, M., AHMADI, M., TULCAN, C., PREJ BEANU, R., DRONCA, D., Rev. Chim. (Bucharest), 66, no. 9, 2015, p.1306.

31.NICULA, M., PACALA, N., STEF, L., PET, I., IANCU, T., DRONCA, D., AHMADI, M., GHERBON, A., DELEANU, B., Rev. Chim. (Bucharest), 68, no. 8, 2017, p.1807.

32.NICULA, M., PACALA, N., RADULOV, I., AHMADI, M., DRONCA, D., GHERBON, A., Rev. Chim. (Bucharest), 2017, 68, no. 9, p.2006.

33.AHMADI, M., NICULA, M., DUMITRESCU, G., STEF, L., PET, I., PETCULESCU-CIOCHINA, L., DRONCA, D., Rev. Chim. (Bucharest), 69, no. 10, 2018, p.2731.

34.MALIK, N., BISWAS, A.K., QURESHI, T.A., BORANA, K., VIRHA, R., Environmental Monitoring and Assessment, 2010, 160, no. 1-4, p.267. 35.AZMAT, H., J AVED, M., ABDULLAH, S., JAVID, A. HUSSAIN, S.M., The J. Anim. Plant Sci., 2018, 28, no. 2, p.201.

36.J EZIERSKA, B., WITESKA, M., Soil and Water Pollution Monitoring, Protection and Remediation, 2006, p.3.

37.GREEN, N.W., KNUTZEN, J., Marine Pollut. Bull., 2003, 46, p.362. 38.VOIGT, H.R., Environmentalica Fennica, 2004, 21, p.26.

39.YU-MEI, H., CHIH-YING, L., SSU-NING, C., WEI-JEN, C., HORNGSHENG, S., MING-I, L., SHU-CHI, M., RU-LAN, H., Scientific Reports, 2017, 7, no. 43608.

40.SHRIVASTAVA, R., UPRETI, R.K., SETH, P.K., CHATURVEDI, U.C., FEMS Immunology and Medical Microbiology, 2002, 34, no.1, p.1.

41.LIU, T., WEN, H., JIANG, M., YUAN, D., GAO, P., ZHAO, Y., WU, F., LIU, W., Fish Physiol Biochem., 2010, 36, no. 3, p.565.

42.HERTZ, Y., MADAR, Z., HEPPER, B., GERTLER, A., Aquaculture, 1989, 76, p.255.

43.SHIAU, S.Y., LIN, S.F., Aquaculture, 1993, 110, p.321.

44.WYSE, E.J ., AZEMARD, S., MORA, S.J ., IAEA-407, IAEA/AL/144, IAEA/ MEL/72, IAEA, Monaco, 2005.

45.*** FEDERAL ENVIRONMENT PROTECTION AGENCY (FEPA), Guidelines to standard for Environment Pollution Control in Nigeria, Lagos, Nigeriam, 1991.

46. GWYNETH, H., Water Quality for Freshwater

$\overline{\text { Manuscript received: } 27.11 .2018}$ 